\title{
Narrative and the social dynamics of magical harm in late nineteenth- and early twentieth-century Finland
}

\author{
Laura Stark
}

Suspicions of witcheraft in Finland did not die out with the witch trials. Traditional forms of magic and sorcery ${ }^{2}$ continued to be not only suspected, but also practised in the Finnish countryside some two hundred years after the last witchcraft prosecutions in Finland, if we are to believe dozens of eyewitness accounts from farmers and labourers in the early twentieth century. ${ }^{3}$ Although descriptions of sorcery and magic practices from the late nineteenth and twentieth centuries rarely entered the historical record, folklore collectors encountered them in their efforts to preserve folk beliefs, which were considered an important national heritage. Perhaps the longest-lived sorcery practices were those in which household witches (trulli) visited their neighbours' cowsheds or sheep pens on the eve of certain holidays such as Easter, Shrovetide and the New Year, in order to milk their neighbours' cows or shear bits of wool from their sheep. The aim of this activity was in some cases the stealing or ruining of their neighbours' 'cow-luck' or 'sheep-luck', but it was also believed that if the witch sheared wool from a magical number of different farms, then she could weave from this wool a cloak which would render the wearer invisible. As late as the early decades of the twentieth century, reports of such acts were sent to local newspapers and to the Finnish Literature Society Folklore Archives. For instance Hugo Hörtsänä, a farmer from Western Finland, reported to the Archives that in 1934 a witch had visited the cowsheds in the village of Hirsilä in Orivesi parish. The sheep of one small farm owner had been sheared of the wool on their heads, under their necks, on their tails, and from the front of their chests. ${ }^{4}$ The same collector also recorded the following account of how such 'witches' were punished: ${ }^{5}$

Circa 1913 on a farm in Orivesi, one night near Easter an itinerant labourer residing on the farm stayed up late at the window of the farmhouse. He noticed someone going into the cattle shed. After waking the master of the farm, they went together to take a look, and there was Emma, the daughter of the neighbouring Onnela farm. They took her out and put a long pole 
through the sleeves of her coat and sent her home along the main road with her arms thus outstretched. Her sister Saima, who was on lookout some distance away, freed Emma from this awkward position. Emma had not yet time to do her magic in the cowshed. ${ }^{6}$

The events described in these stories represent the tail-end of an iceberg, namely the final decades of a rich and long-standing tradition of sorcery in rural Finland. It is a striking fact of agrarian Finnish culture that it managed to preserve magic practices, beliefs and incantations in traditional poetic metre (certain motifs of which probably date back several millennia) until the early decades of the twentieth century. The tenacity of this historicallylayered traditional world-view can be seen from the tens of thousands of descriptions of magic rites and over 52,000 recorded variants of magic incantations recorded in the nineteenth and early twentieth centuries from the agrarian populations of Finland and neighbouring Karelia. ${ }^{7}$ These descriptions and incantations were first recorded by educated collectors in the 1830s, and later also by tradition enthusiasts coming from the ranks of the rural population (1890s onward). These latter collectors from the writing folk' sent their written recollections and those of their neighbours and kin directly to the Finnish Literature Society Folklore Archives in Helsinki.

For the narrator, and often the collector as well, the social context of sorcery was so familiar and taken for granted that it was rarely considered necessary to verbalize it. Yet for today's folklorist or oral historian, this context represents unknown territory. Without information concerning their social setting and underlying motivations, practices aimed at magical harm may appear as dark, mysterious, anti-social events completely divorced from normal, everyday social interaction and experience, or opposed to social integration and cohesion. In this chapter I draw upon over 300 narratives recorded in rural Finland in the late nineteenth and early twentieth centuries that provide information concerning the social relations, tensions and strategies that framed sorcery and the counter-magic employed against it. Folklore is an important source for the study of these magic practices, because even if we are dubious of a source narrative's accuracy in all details, the communicative content of folklore, the fact that it was intended to be intelligible to others in the community, means that it can illuminate the background knowledge regarding sorcery's place in social life which is not always available from historical documentation. Although folklore often falls short of meeting the historian's standards for precision in form and chronology, and often lacks support from other documentation, ${ }^{8}$ these shortcomings become less relevant when what we seek from folklore is not necessarily verifiable historical fact but the semantic field of cultural thinking about magical harm.

Since members of the rural populace rarely wrote down their own feelings or experiences, descriptions of magical self-protection and aggressive sorcery 
provide rare insights into the kinds of social pressures and tensions people experienced in their everyday lives. By looking at what people strove to gain by working magic and how magical acts were justified through different types of discourse, we learn much about early modern notions of personhood. The desires and impulses expressed through sorcery were framed within historical and culturally-specific ideas concerning legitimacy, entitlement and rights of the individual, the ways in which ego identified with others, the boundaries of the body and self, and how the violation of the self was experienced through the cultural filter of normative emotional expression. One fact which is clearly revealed from the folklore is that magic was a form of social currency, an instrument in power struggles and socio-economic strategizing. Magical knowledge and practice can be seen both as a tactic, ${ }^{9}$ and as units of symbolic cultural capital ${ }^{10}$ which could be exchanged for prestige, recognition, or material goods.

Yet the role of the emotional, irrational or unconscious cannot be overlooked here. Finnish folk narratives speak volumes on hostility, quarrels and violence, the lack of empathy towards enemies who suffer appalling fates, and the value of anger as a personal resource, both in daily life and in the cultural imagination. One may speculate that if Keith Thomas had been able to include folk narratives of witchcraft in his data, he might have been less inclined to emphasize the prevalence of harmony and conformity in sixteenth- and seventeenth-century English village life. ${ }^{11}$

\section{Sorcery and social tensions}

Although cultural representations existing in the memories of informants and expressed in folklore do not directly reflect social reality, such representations nonetheless originate within the context of real-life conditions and reflect, moreover, what the informants themselves saw as relevant. Memorates and anecdotes concerning sorcery can thus provide glimpses into the social structures and behind-the-scenes power struggles which operated in rural Finnish life. The ways in which human relationships were organized and manipulated through sorcery point to some of the most serious tensions plaguing this society, supporting the notion of "witchcraft as a social straingauge'. ${ }^{12}$ Although all manner of disputes and conflicts could give rise to sorcery, generally speaking the majority of stories depict farming or crofting households in ongoing competition with each other, although cases in which beggars went away empty-handed and muttering a curse ${ }^{13}$ comprise their own clear sub-category of sorcery narratives. The reputations of 'witches' (noita) were thus rooted in tensions which were both vertical and horizontal with regard to social class structure.

Sorcery and magical harm practised by neighbouring farm households against each other can be understood in part as a result of resource scarcity 
and the notion of 'limited good', ${ }^{14}$ in which it was assumed that the good fortune available to a community was of a fixed amount, so that a person prospered only at the expense of others. The concept of 'limited good' in Finnish and Karelian folk belief was already identified in 1960 by Toivo Vuorela. ${ }^{15}$ This cognitive orientation was expressed in the Finnish-Karelian culture area through the concept of 'luck' (onni), which was thought to exist in finite quantity, as well as the 'stealing', 'spoiling', or 'breaking' of this luck. If a cattle owner's onni decreased (the cows became sick or stopped giving milk, for example), then it was assumed that the cattle-luck of a competitor had correspondingly been increased through unnatural means. Suspicions of sorcery were not merely a figment of farmers' imaginations: there is ample evidence that farmwomen, in particular, actually carried out harmful magic rites against their neighbours' livestock.

Finnish folk narratives regarding sorcery address (1) how the landless poor used their magical knowledge as a medium of exchange or barter to gain material goods; (2) how, as a last resort, the landless poor could receive negative respect and coerce material benefits from landowning farmers by cultivating a reputation for magical harm; (3) the use of sorcery in maintaining group cohesion and defining the symbolic boundaries of the farm household; (4) the key role of counter-sorcery in defusing aggression and providing an alternative to physical violence; and (5) the ways in which magical harm was collectively categorized as either legitimate or illegitimate.

\section{Knowledge as social capital in the magical marketplace}

Rapid population growth throughout the nineteenth century and especially famine in the 1860 s gave rise to large numbers of itinerant labourers and beggars roaming the Finnish countryside, seeking room and board in exchange for performing menial labour such as chopping wood or bathing household members in the sauna. Such dependent lodgers were allowed to sleep in a corner of the main farmhouse or in an outbuilding. Although they might settle on a farm for decades if treated well, most itinerant labourers, and women who wandered the countryside in the capacities of masseuse or 'cupper', ${ }^{16}$ were highly mobile, and thus able to pick up all manner of useful information.

Those who were most restricted to the domestic sphere, on the other hand, were farm mistresses, who were responsible for food preparation, cleaning, livestock husbandry, spinning, weaving, sewing and childcare, among other tasks. This contrast between the relative immobility of married women in the landowning classes and the much greater freedom of landless men and women gave rise to an information network operating behind the scenes of formal public power. Through this network, farm mistresses used 
the services of lower-class men and women in order to extend their own power and influence beyond the limits of the domestic sphere.

A farm mistress might send landless women on errands of either strategic information gathering or dissemination of information, in order to find a suitable bride for her son, sing her daughter's praises when visiting certain farms, spread false rumours in order to break up a liaison between her son and an undesirable young woman, or discredit a rival of her daughter. ${ }^{17}$ Such errands furthered the farm mistress's own goals, and the messenger was repaid with food or even a bit of cash from the farm household, often without the knowledge of the farm master.

The information provided by the ranks of the landless poor also included knowledge of magic and sorcery. In some narratives, feuding farm households could use the magic knowledge possessed by the landless poor against each other:

There lived two families, the Kekkonens and the Kestiläs. The farms were near each other, but in the middle was a patch of unused forest. The two farms quarrelled often with each other and tried in all ways to torment one another. One evening an old wandering beggar happened to come to Kestilä farm, and asked to spend the night. The farm master asked whether the stranger had in his power any 'wizardry', that is, the ability to harm others through magical means. The stranger answered in the affirmative. The farm master asked the stranger to stay the night, but at the same time urged him to summon a bear to attack the cattle of Kekkonens' farm. The stranger said he would do it, but announced that for that he would need a heated sauna, in which he could bathe. The sauna was heated, the stranger bathed and in all respects enjoyed the hospitality of his hosts. ${ }^{18}$

Itinerant labourers and beggars could also assist in healing illness or solving a theft, and they were, moreover, called upon to give advice on sorcery so that members of the landowning classes, especially farm mistresses, could advance their long-term socio-economic interests within the farm household. According to informants, those landless women who provided the farm mistresses with gossip or news of a prospective bride were also the same women who gave them advice about love magic or performed magic for them 'so that young lovers would stop seeing each other or so that an objectionable daughter-in-law or son-in-law would not come to the farm'. ${ }^{19}$

The women of the farm household had to work closely with each other in their various daily tasks, and were therefore greatly concerned about who shared the domestic sphere with them. This explains why farm mistresses occasionally performed sorcery to 'break' or 'ruin' the relationships their sons had formed with girls from poor families or those considered lazy, ill-tempered, sickly or unskilled. In a three-generational household, a new bride was also an important determinant of her mother-in-law's future well-being. It was the daughter-in-law who would eventually usurp the older 
woman's power and become mistress as the latter grew ill or frail, and whose kindness or ill-treatment would determine the quality of the mother-in-law's final years. ${ }^{20}$ The adult women of the household were often those with the least official 'say' in matters of matchmaking. And because marriage was a socially-approved goal and the 'breaking' of a married or betrothed couple was disapproved of, the farm mistress could not in this case turn to a tietäjä for help.

Knowledge of magic and sorcery was an especially valued form of cultural capital because it was secret. Tanya Luhrmann, who has conducted fieldwork among modern magic-users in England, argues that secrecy is the key to the power of magic, because through restriction and concealment, knowledge becomes valuable, and its possession differentiates the possessor from other persons. ${ }^{21}$ Knowledge of magic thus becomes a resource that others would like to obtain for themselves. Although secrecy was the apparent aim of magic rites in nineteenth- and early twentieth-century Finland, in reality the lack of privacy in Finnish rural life meant that very little escaped the attention of other household members and neighbours. The more secret the knowledge, the more it aroused interest among non-participants who tried to gain access to it through secretly listening at doors and peering through peepholes, or watching magic rites while hidden in the forest. ${ }^{22}$ The circulation of information was, in fact, the deliberate goal of the magic-user in many cases. By threatening one's enemy openly with future sorcery, ensuring that a witness 'accidentally' saw the sorcery being carried out, or whispering to select confidantes of the possibility that 'secret' rites would be carried out on a given day or at a given time, the performer could guarantee that the act of magical harm would be witnessed or at least guessed at, and reports of it be circulated widely. Because persons were eager to demonstrate to others their possession of exclusive knowledge, both eyewitness accounts and narrative descriptions of magic were routinely broadcast by word of mouth. This in itself apparently led to concrete results, particularly in the case of unsolved theft: according to several accounts, stolen goods were secretly returned or confessions made as soon as the thief heard that a powerful tietäjä was on the case and preparing to either identify him or cause him harm through sorcery. ${ }^{23}$

Some persons made a career of the possession of secret knowledge. The tietäjä (lit. 'one who knows') was a seer, healer and sorcerer with shaman-like features ${ }^{24}$ who possessed the most elaborate and structured knowledge regarding the supernatural. Most tietäjäs were men, although some were women, particularly in the northern parts of the country. Well-known tietäjäs were accorded respect just as were master craftsmen such as blacksmiths, carpenters, masons, bricklayers, fiddlers and castrators. Tietäjäs cured illness, retrieved stolen property, and performed lempi-bathing rituals on young women in order to increase their sex appeal to suitors, among other 
things. Like master craftsmen, tietäjäs were usually not paid in money but in kind, with a bottle of alcohol being the most usual gift. ${ }^{25}$ To underpay a master craftsman meant that one did not respect his work, and it was common knowledge that in this case the 'master' might leave an intentional flaw in his work which would then be repaired or removed if shown the proper appreciation through an appropriate gift. In the same way, tietäjäs who were not appropriately compensated could turn magical protection into a curse.

\section{Reputations for magical harm}

Those whose magical knowledge was not necessarily in demand at a given moment could still coerce assistance from farm households by hinting that terrible supernatural revenge would follow if they were slighted or turned away empty-handed. Intimating at possession of powerful magical ability or secret knowledge through intensity of gaze or strange facial expressions, or by carrying mysterious-looking pouches and recounting their own feats of sorcery, gave the landless poor a certain leverage in soliciting charity from wealthier peasants. One informant recalled an elderly beggar who visited his childhood home at the end of the 1870s: 'she had been married to four men and then remained a widow and roamed about, begging and telling the most frightening tales of her magical abilities, so that farm mistresses, in their fear, put all kinds of things in her begging-sack'. ${ }^{26}$ Another account reads as follows:

I remember how dreadfully afraid we were of the sorceress named Pykly. I was a small girl on my home farm of Emoniemi. It was a completely different time than now, there were no railroads, nor anything else that was modern. The old beliefs were still alive. Every once in a while our home farm was visited by a tiny, old, extremely dark-complexioned woman with a bundle in her hand. She was the dreaded sorceress Pykly, with her magic objects in her bundle. 'Pykly is coming', it was said, 'now children, behave.' Cold shivers ran up and down my body. I would have wanted to run away, but there was nothing to do but remain in the farmhouse and be good, so that Pykly wouldn't work her magic. The adults tried to curry favour when dealing with Pykly. She was fed and given drink and gifts. Pykly was a malicious old woman, from whose brown face blazed a pair of keen black eyes. And she was capricious and quick to anger. Everyone heaved a sigh of relief when she left the farm. Many people used Pykly's 'services' during their lifetime. Pykly was in fact a capable sorceress, so it was said. ${ }^{27}$

Surprisingly large numbers of beggars and itinerant labourers appear to have been able to obtain food from farm households in the late nineteenth century. Given the fact that poor relief institutions were in their infancy, efforts by the political and cultural elite to stem the tide of beggary had little 
effect in the famine-ridden areas of northern and eastern Finland. While some farmers saw it as their Christian duty to assist the needy, many gave alms out of a deeply-rooted belief in the limited nature of good fortune which made them afraid of exposing their own hard-won resources to magical 'breaking' or 'ruining'. Narratives tell of households which refused charity to persons they mistakenly took for ordinary beggars and thereby suffered the consequences, whereas those who correctly identified which beggars were skilled in sorcery were able to appease them and thus escape magical harm. Correct identification, in turn, was aided by the circulation of folk narratives which told of well-known figures in the village or parish, as was the case with Poor-Lawrence (Köyhä-Lauri) from Uukuniemi in South Karelia, who was said to have bewitched livestock and magically prevented wedding guests from leaving weddings when refused food or alcohol. Poor-Lawrence was considered such a powerful sorcerer that if necessary he could have set all the denizens of the graveyard in motion'. ${ }^{28}$ Narratives suggest that the most sensible precaution in dealing with beggars was a thorough knowledge of their reputations so that those who were versed in magic could be recognized and placated through gifts. This sort of almsgiving, while outwardly reminiscent of charity, was motivated by anxiety and self-interest rather than philanthropy.

Witches in the Finnish countryside were not simply suspected of harbouring resentment against those who withheld alms, they themselves made it clear, through boasting of their own skills in sorcery and actual performance of magic rites in full view of the farm household, that refusal of charity would not go unavenged:

In order to demonstrate how much people feared 'breaking' and other sorts of ruinous magic practices, I tell the following story here: In a neighbouring parish, there lived in the days of my childhood a certain man who had made it his habit to travel from farm to farm every year in the late summer, not only in his own parish, but also in neighbouring parishes to claim his butter tax or tithe just like a clergyman, even though he hadn't any more right to it than a common beggar. ${ }^{29}$

When this 'tax man' came to collect his due, as he put it, he asked for nothing, unlike others who would receive favours for free, instead, he wrinkled up his nose and twisted his jaw and said, 'now I came to collect my butter tax'. He needed say no more, and in some places didn't even need to say that much, before the butter pat was brought to him and he was humbly asked not to consider it too mean a gift by reason of its paucity or something else, but in no case was it said that the 'tax man' had no particular right to what he received.

In addition to his pat of butter, the 'tax man' was given food and drink. You see, he was so feared for his sorcery that his hosts tried to be as humble and obedient as they possibly could. If, in his opinion, he was given too little, then he rarely complained about its paucity using words, 
instead he wrinkled his nose and twisted his jaw even more, so that his face was puckered up. And then upon leaving he began his magical machinations, at the other end of the field if not before, thus frightening the people on the farm.

With these sorts of schemings he had made himself so frightening that farm mistresses, even farm masters, began to tremble with dread when this 'tax man' visited the farm. Once, however, it so happened that three men from one farm went after him and when they found him working his magic, they gave him quite a thrashing, and that's what he should have received from each place he visited instead of butter and refreshment, that dirty blackguard, but nobody dared to do it, they just waited on him hand and foot like a bishop in the parsonage. ${ }^{30}$

Not only begging but also petty theft might be tolerated if the perpetrator was known to be skilled in sorcery. One account from Eastern Finland describes a wealthy farm whose household members were well aware that a gravedigger was stealing grain from their granary to feed his family in the winter but dared say nothing about it because he was known to be a powerful sorcerer. ${ }^{31}$ Such sorcerer-beggars may have been tolerated not only because members of the community believed in the efficacy of their magic, but also because they could be useful when one wished to perform sorcery against a third party. Itinerant beggars who visited farms or crofts where illness had suddenly or mysteriously arisen were in a position to benefit from their own claims of skill in counter-magic, and narratives suggest that their advice on magical matters was usually well received and rewarded.

Despite the frightening reputations of sorcerer-beggars, fear of the tietäjä's ability to work magic was even greater, and ensured that few dared to offend him deliberately. In one narrative, a farm master absentmindedly drove his wagon home past a known tietäjä walking some kilometres outside the village without inviting him in for a ride. The next morning the farm master's horse was seriously ill, having been 'eyed' by the tietäjä, but was cured when the farm master went to the tietäjä to kindly ask for help. ${ }^{32}$

It was especially dangerous to offend a tietäjä because the tietäjä’s power or magical force was seen to come directly from his anger, ${ }^{33}$ and could not always be countered through rituals or by injuring him. The famous tietäjä Pekka Tuovinen, for instance, told a folklore collector how a farmhand had vandalized a trap set for birds by an elderly tietäjä, despite warnings from others. 'At this the old man became furious. And later, when the farmhand went insane for the rest of his life, the old man said, "I became too angry, he cannot be saved", when he was asked to grant mercy.' ${ }^{34}$ In another account, a man who had verbally offended the tietäjä known as 'Doctor Hirvonen' died of a haemorrhage the same night: 'Doctor Hirvonen said of himself that the person at whom he became angry would die right away.' ${ }^{35}$ 


\section{Sorcery and the farm household}

Throughout Finland and Karelia, farming households formed the basic unit of society, the fundamental community with which the individual most closely identified. For various reasons associated with land shortage and the low productivity of agriculture which resulted in the need for household members to engage in several different economic occupations simultaneously, actual farm households were quite flexible in terms of size and membership. Household members might not necessarily be related by blood or marriage, but might include unrelated 'partner families' and servants. ${ }^{36}$ More important than blood ties was the fact that the Eastern Finnish and Karelian farming household ideally comprised a fundamental 'eating community', an aggregate which was seen to function as a single unit of social and economic production and consumption.

Descriptions of sorcery make it clear that in rural-traditional Finnish communities suspicions and accusations of sorcery tended above all to reinforce the boundary between separate farming households. From the perspective of landowning peasants or crofters, those who posed the greatest threat of magical harm were their neighbours. Narratives regarding sorcery reflect a cultural ideal in which the household was imagined to function as an integrated and harmonious whole. Tensions within households undoubtedly existed, but in numerous descriptions of sorcery, these tensions are silenced and glossed over, and it is the tensions between households which are emphasized. If, for example, household members or livestock fell ill or otherwise failed to thrive, the witch was never seen to be a member of the same farm household as the victim. In some cases the sorcerer and victim might even be related (as brothers, cousins, or in-laws), but lived in competing farm households, especially those which might have split off from a larger farm or were involved in disputes over inheritance or land use. ${ }^{37}$ The only time that sorcery was seen to occur within a farm household was when an older woman performed sorcery on her son's new wife, if the incoming bride was seen to be a threat to the farm's continued prosperity.

For individuals and households who feared they were victims of magical harm, the primary recourse was counter-sorcery performed by a tietäjä. The identity of the sorcerer who had worked his or her magic against a farm was not always known at the moment in which counter-sorcery was undertaken. Yet it was believed that the agent of magical harm (referred to as a ' $d \log ^{\prime}$ ') would find its own way back to its sender or 'master', even if this sender had not yet been identified. If sent back to the witch, the 'dog' was thought to attack its master or mistress even more furiously than it had attacked its original victim, causing sudden pain, illness or even death, according to the tietäjä's instructions. ${ }^{38}$ At this point the witch could be identified, once word circulated through the village that someone had 
suddenly suffered an inexplicable attack of pain or illness. The following narrative was sent to the Finnish Literature Society Folklore Archives in 1921 by a man born and raised in rural Eastern Finland, and depicts such an event which took place in his childhood:

Once, the majority of the members of our household were feeling rather poorly. At that time, you see, nothing seemed to be going quite right in our life. Somebody had 'broken' the entire household. It was therefore necessary to fetch a sorcerer from somewhere who would correct the problem, release us from this 'breaking' [= magical harm], send the dog to its home, as was said concerning release from 'breaking'. That sort of sorcerer could be found some twenty or thirty kilometres from our farm, and so he was fetched.

For smaller difficulties, 'releasers' could be found from closer at hand, from one's own village, in fact, but none of them could release a person from more serious 'breaking'. For that, he had to be an entirely 'toothy-mouthed man', ${ }^{39}$ a man who knew all the magic tricks, who could put the Devil himself in pincers, who could drive a knife into his heart.

And so! That sorcerer fetched from afar was, or at least pretended to be, the sort who was fully capable with his magic of making the Devil tremble in his trousers, of making the Evil One flee. And so the sauna was heated and the entire group of us, from the father of the family to the smallest child, went to the sauna with the sorcerer. There the demon-frightener first bathed us, slapping each of us separately with the sauna whisk made of birch leaves, and at the same time reciting an incantation so that he foamed at the mouth. Then he put each of us three times through a hoop fashioned from the blades of three scythes, first by lowering the hoop over each of us from head to foot two times, and then one time from bottom to top. While doing this trick, the sorcerer was in an extremely agitated state the entire time, but that was still nothing compared to what happened next. Now, you see, the sorcerer encircled each of our heads with a hunting knife, two times clockwise and one time counter clockwise, and then in a fit of frenzied rage, hurled the knife into the sauna whisk lying on the floor, and then, holding the knife, flung the whisk out of the sauna window and against the cooking hut so that the wall of the cooking hut reverberated. Apparently in this way he flung out our tormentor, supposedly pierced to the core by the knife, thus sending the dog to its own home to bite and gnaw the person who had 'broken' us.

That sorcery seemed to have been very effective. A certain person living not far from us was heard to have become so violently ill in the same moment that he ${ }^{40}$ nearly died. You see, a 'dog' sent home in the proper manner was exceedingly severe, it could kill the 'breaker' where he stood, depending entirely on what the person who sent it home wanted it to do. The sorcerer, in fact, usually asked the person he cured, from whom he sent the dog home ... how severe should be the bite of the dog sent home, should it kill right away, or merely torment?

Usually people were sufficiently merciful toward the 'breaker', so that his life was spared, but otherwise to be dealt with as harshly as possible, since he had worked his magic in the first place without reason, in order to harm 
another. Therefore that worthless lout should receive his just reward, and so be less willing to start bewitching a second time.

The release of our household from the 'breaking' occurred in the winter. In the spring, we boys found the sauna whisk which had been thrown from the sauna to the cooking hut, about a half kilometre from our farm, near the road that led to the cottagers who lived on our land. Apparently our sorcerer had taken it there, had given the 'dog' a ride that distance from our home. When we took the whisk apart, we found inside it a forked piece of alder wood about six inches long, and a bundle of alder twigs wrapped in the red string usually used for working magic.

That forked piece of alder wood in the whisk was naturally standing in for the person whom the 'dog' was sent back to bite. It was that piece of alder at which the sorcerer had aimed the thrust of his knife at the same time that he had chanted the incantation and glared and distorted his face in such a horrible manner.

I still remember the words of the incantation: 'Go, dog, to your home / to your master by supper / to your mistress by breakfast / to the rest of your family by mealtime / to bite, to gnaw / to cause extreme pain / Go far from the blameless / skirt round the innocent / go past the decent people.' ${ }^{41}$

Because the witch's fate hung in the balance between life or death, solely dependent upon the choice made by the victimized client, the tietäjä's countermeasures gave the client a sense of empowerment and functioned as an effective channel for clients' aggression and desire for revenge. Numerous accounts tell how tietäjäs gave their clients the choice of whether or not to 'send the dog back to its master', and if the answer was yes, how much damage the dog should do. While most clients asked that the witch's life be spared, others were reportedly not as merciful.

Despite the large number of narratives depicting acts of sorcery and the widespread fear in their efficacy, there is only one mention that sorcery-related cases were ever brought before the local courts by villagers, and there is no indication from the folklore materials that villagers were ever brought to trial for their over-zealous punishment of suspected sorcerers. ${ }^{42}$ In general, retribution against witches tended to assume the form of counter-sorcery rather than physical violence. Only in cases where the witch was caught in the act was physical violence carried out: ${ }^{43}$

An old story of a witch from Vesanka village in Jyväskylä parish, which took place about one hundred years ago.

In the aforementioned village there was a certain farm mistress known for working witchcraft. And once she had been offended by something her neighbours did, and she began to summon a bear against the neighbour's cattle, so that it would attack the cows. She went to the forest near her neighbour's farm, where she knew her neighbours' cattle grazed during the day and began to climb up a tree upside-down so that her feet were in 
the air, and naturally in this way she was not able to climb very high. ${ }^{44}$ But the master of the neighbouring farm happened to notice the mistress going secretly off into the woods, and he followed her in secret to observe what she did, and crept silently after her carrying a switch in his hand. When the mistress began to climb backwards up the tree, the master came up to her immediately and began to hit her on the backside with the switch while the mistress was still hanging onto the tree trunk with her feet in the air. The mistress yelled for help and did not manage to harm the neighbour's cattle, since her witchcraft had been interrupted in this way. ${ }^{45}$

While we may view the factuality of these narratives with a critical eye, keeping in mind their entertainment function, one thing is clear: these tales circulated by word of mouth for decades as part of a living oral tradition, which indicates that the world-view attributed to the characters in the narratives (in which climbing into a tree backwards or entering a neighbour's cowshed signified an intent to work witchcraft, constant watchfulness and suspicion of sorcery were commonplace, and mention of hostilities between farm households needed no further explanation) must have been to some extent familiar to both narrator and audience. Storytellers and listeners appreciated the tales because they understood the attitudes and background assumptions depicted in them, and any narrative gaps regarding context or motivation would have been filled in from knowledge of similar stories or even personal experience. The line between descriptions of actual magic practices and tales of magical fantasy is a hazy one, because as long as they were theoretically possible to carry out, the methods mentioned in even fanciful tales of sorcery could always serve as models for real attempts at magical harm. Oral tradition was therefore both the message and the medium of magical knowledge; it described sorcery practices while serving at the same time as the very means by which cultural knowledge of these practices was disseminated.

\section{Legitimate versus illegitimate sorcery}

Narrative accounts indicate that an important aim of sorcery was to prevent the dissolution of pre-existing social relationships. Numerous narratives allude to failed expectations regarding gifts not given (alms, hay from a neighbour's meadow, the milk or beestings from a neighbour's newly calved cow) yet the narratives do not go into the background of these expectations, to explain how the gift may have been awaited in return for a prior favour, for instance. What is depicted instead is a single act of charity refused at a particular moment in time - and this makes it difficult to reconstruct the social context behind the expectation or its refusal. In some cases, though, it seems clear that sorcery was used by dependent persons to prevent more powerful persons from breaking off relations of giving or exchange. In other 
words, the sorcerer was the weaker party, in danger of being excluded from a network of reciprocity from which he or she benefited. For instance, in speaking of the tensions in the tenant-landlord relationship, social historian Matti Peltonen points out that it was not the land tenure system and the dependence that it engendered per se which aroused bitterness in the crofter class, it was instead the breakdown in this system. During the period 1901-15, roughly 16,000 crofters were evicted from their homes by landlords who themselves were under new economic pressures. ${ }^{46}$ This is reflected in the recollected narratives on sorcery as well, in which tenant farmers boasted of having caused magical harm to their landlords when their ties of interdependency had been, or were about to be, severed:

I lived for eight years on the Kuusenjuuri croft in Mulikka village, Pylkönmäki district. Since I didn't have a written contract, the master of Hokkala farm evicted me. Some time later I met an old Lapp man ... When he heard my story, he said: 'would you like for the entire family to become poor?' 'So be it,' I said. And thus it actually happened, the entire Hokkala family is now penniless. ${ }^{47}$

Another important context for sorcery was the power struggles that arose over disputes concerning theft, wages, or fair exchanges in barter. These were often disputes in which questions of legitimacy were unclear, often due to insufficient evidence to sway others to one's point of view. The motive behind the sorcery in all of these cases appears to have been the overturning of the sorcerer's position of dependency and powerlessness. When a neighbour's child fell ill, her cow was bewitched to stop giving milk, or a bear attacked her cattle, she was often forced to go to the sorcerer to ask for mercy, a request that was usually granted. Unlike the counter-sorcery in sixteenth- and seventeenth-century England described by Keith Thomas, in which the victim's aim was to compel the witch to ask for mercy, here it was often the victim who was forced to seek the mercy of the witch. In this way, the sorcerer strove to maintain the power equilibrium between self and victim which had been under threat:

In former times when I was a child, my sister fell ill with epilepsy and people said that the girl is in the clutches of a sorcerer, of one old man, whose wife brought my mother berries ${ }^{48}$ but in her opinion did not receive enough flour in return. Because my sister was the one to eat those berries first, it was said that the old man had bewitched the berries. Years later, my ailing sister went to this same man's house to ask if he would cure her of the illness, since he had been the one to bring it in the first place. The old man agreed and my sister told that he had proceeded in the following manner: 'we went into the forest and with the old man made a naara church from saplings (one naturally makes a cross with the trees so that it looks like the walls of a barn). Then a fire was lit in its corners and I had to walk through the hole of the window while they were burning. Then I had to take off my shirt and 
burn it on a low, flat stone. During this whole procedure, the old man was mumbling something I could not make out.' ${ }^{49}$

Yet while the sorcerer may have hoped to force his/her victim to ask for mercy, in some cases persons went to apologize to and seek mercy from their tormenters only after months or even years, or after having sought the aid of other sorcerers (minor healers and tietäjäs). For the victims, humbling themselves and asking for mercy was a last resort. In many narratives, the story concludes instead with a third-party tietäjä healing the victim, and in some cases giving the victim the choice of whether or not to send the illness or harm back to its sender.

When was sorcery seen to be an act of illegitimate aggression, and when was it an act of self-defence or justifiable revenge? An analysis of folk narrative suggests that rural communities had their own value system and cultural categories for interpreting magical harm and human agents of sorcery. While some types of malevolent magic were clearly viewed as acts without social justification, other cases of harmful sorcery could be seen as defensible, as stabilizing social relations rather than escalating tensions.

On the basis of the folk narratives it appears that magical harm was divided on the one hand into categories of socially justifiable versus unjustifiable types of magical harm, and, on the other hand, pre-emptive sorcery, retributive sorcery and counter-violence. Combining these gives us, in theory, six different types of harmful magical acts. Socially justified, retributive sorcery included sorcery carried out against persons who insulted or refused to help the magic-user, or whose acts threatened the peace and order of the community, but above all the inviolability of the individual and his property. In practice this meant the identification and/or supernatural punishment of thieves, vandals and rapists. ${ }^{50}$ It also included sorcery to punish men who had fathered children (especially by serving-maids) but refused to take financial responsibility for them. ${ }^{51}$ Second, we have socially justified countersorcery which included sending back the 'dog' (e.g. illness-agent or bear summoned to attack an enemy's livestock) to its master. Tietäjäs might assist clients in both of these cases of socially justified magical harm:

When about 60 years ago there was a bear in the midst of my cows and I found out that my enemy, the witch Nuija-Taipale from Ruovesi parish had bewitched it to attack my cattle, I went to the witch Kyyräläinen in Saarijärvi parish to ask for help. Kyyräläinen asked me: 'shall I send the dog home?' To which I answered, 'Do what you like, I'll not interfere.' The next day a bear attacked my enemy's cattle and killed his only cow, while the 'farmed-out cow' (which was rented to him for a year at a time in return for payment) was let alone. ${ }^{52}$

In traditional Finnish narrative, pre-emptive sorcery was never presented as justified. Persons who committed unjustified, pre-emptive sorcery generally operated alone, without the assistance of tietäjäs. Unlike the case made for 
early modern England by Thomas, most perpetrators of magical harm were not those most dependent upon neighbourly support; instead, they were persons who were only momentarily or situationally powerless, that is, they found themselves in situations in which sorcery was their only option. For example, with less freedom and mobility, but a considerable amount of power at stake, the goals of women of the landowning classes often ran counter to the goals of those who represented 'public good', namely farm masters. Because a rural Finnish woman's position in her marital household was often tied to the amount of milk produced by her own cattle (which she had brought with her as her dowry and therefore owned), examples of pre-emptive, illegitimate sorcery by women in rural Finland included the 'stealing' or 'breaking' of other households' cattle-luck. ${ }^{53}$

Another example of such illegitimate sorcery was love magic, an aggressive act of bewitching in which unmarried women placed their own bodily substances (menstrual blood, sweat, hair, etc.) in food or drink offered to the man whom they desired as a husband, but could not attract by other means, often a man of higher social standing. Numerous folk beliefs and personal reminiscences recorded throughout Finland and Karelia attest to the fact that both women and men believed in the effectiveness of this magic. ${ }^{54}$ Women either practised love magic alone or were aided solely by their mothers, and generally only received assistance from outside sorcerers when the sorcerer wished to barter his/her knowledge for food or coffee.

Following the logic of the categories given above, one might also expect to find narratives regarding unjustified retributive sorcery and unjustified counter-sorcery, yet these do not seem to have existed in the Finnish folklore tradition. The reason for this is that retributive sorcery and counter-sorcery, as narrative devices, were always viewed as justified in order to signal the illegitimacy of the original, pre-emptive magic which preceded it and the guilt of the initial aggressor. Such counter-measures mentioned in the narratives also included physical violence, for example violence carried out against women by men who suspected themselves to be the victims of love magic. ${ }^{55}$ In other words, when counter-sorcery was mentioned in the narratives, its function seems to have been to depict a situation in which social justice prevailed and equilibrium was restored. To have suggested that counter-sorcery was unwarranted would have violated these norms for storytelling. When, on the other hand, the narrator wished to signal that the first act of retributive magical harm was justified, then the story simply did not mention counter-measures at all. ${ }^{56}$ The fact that punished sorcerers did not pursue their grudges in the stories' narratives does not necessarily reflect the ethnographic reality but rather the internal value system of the narratives, as well as the fact that the narratives tended to capture frozen moments of time rather than the diachronic processes of long-term hostilities.

Folk narratives also used other devices to signal whether the sorcery 
depicted in them was socially acceptable or unacceptable. Stories warned how the use of love magic by women in order to ensnare husbands, for instance, could end in the suicide or insanity of the husband, or the attempted murder of the wife:

Just after the master of Pyykkö farm was fed the magic substance, they were married, but the couple became quarrelsome even though they had five children. The man was once again hostile: almost immediately after the marriage the feeling of closeness ended and in its place came the former feeling of disgust and revulsion. After having been married for about ten years the man went crazy and once he tried to kill his wife in the meadow with a scythe, but the wife got away. ${ }^{57}$

Sorcery that was seen to be justified, on the other hand, did not give rise to narratives that warned of the fateful consequences awaiting the magic-user.

Sorcery in the late nineteenth- and early twentieth-century Finnish countryside did not represent merely the vestiges of a once vital tradition, but comprised instead a system whose internal mechanisms were still functioning as late as the 1930 s in some parts of the country. These mechanisms included belief in the efficacy of magic, circulation of narratives regarding sorcery, valuation of magic as cultural capital and the communal assessment of the legitimacy of different forms of magical harm. In the final analysis, sorcery in this cultural context appears to have been a strategy by individuals striving to maintain both their own social standing in society and their links to other persons. Exclusion from a relationship of aid or assistance was simultaneously a loss of one's place in the social matrix, and the insults that commonly sparked retributive sorcery likewise stripped persons of their social face. Persons undertook retributive sorcery in an attempt to maintain collapsing relations of dependency, whereas counter-sorcery was often a means by which households disengaged themselves from ties with non-beneficial groups or individuals while emphasizing their own internal cohesion.

Witchcraft accusations and the actual identification of witches seem to have played only a minor role in the sorcery dynamics of rural Finnish society when compared to the situation following the period of witchcraft trials in other parts of western Europe. Because the sorcerer did not lose face or social position by being suspected (sometimes quite the contrary), accusations were never an end in themselves, and public accusations are never mentioned in the narratives. To be known as a 'witch' (noita) was not necessarily a stigma to be avoided at all costs, since a reputation for magical harm elicited respect from others. The sorcerer or witch was never accused and then asked to remove a curse or pronounce a blessing. ${ }^{58}$ The magical harm of sorcery could only be countered through supernatural strength or by crushing the sorcerer's will through frightening counter-measures, which included 
'sending back the dog' and occasionally physical violence. One observation which emerges from my reading of the narratives is the importance of counter-sorcery and the role of the tietäjä in providing a legitimate outlet for airing grievances and tensions. From the Finnish material it appears that victims of supernatural misfortune placed their trust either in their own ability to counter sorcery, or in the tietäjäs capacity to find and punish the perpetrator, and therefore had no need to expend energy in ferreting out the evil-doer themselves, causing them bodily harm, or venting aggression against them in the form of long-term persecution.

In these folk narratives which highlight the tensions and tactics of everyday socio-economic struggles, sorcerer and victim appear as rational actors, even if they cannot always be pinned down with historical precision. Narratives were the modus operandi by which sorcery beliefs and practices were created, shaped and evaluated. When magical information was made more valuable through secrecy, this facilitated the circulation of narrative descriptions concerning it. Memorates and anecdotes simultaneously evaluated motives and situations, classifying them into socially acceptable and unacceptable forms of magical harm. By functioning as mechanisms of social ethos and control, narratives of magical harm were assured a place at the very heart of rural Finnish social dynamics into the twentieth century.

\section{Notes}

1 The author would like to thank the Academy of Finland for its funding of the research upon which this chapter is based.

2 The term sorcery here refers to magical harm caused by a human agent. Particularly in the eastern parts of nineteenth-century rural Finland, most sorcery beliefs had little diabolic content. Because a common term for sorcerer in Finnish, noita, has nonetheless been commonly translated into English as 'witch', I use the terms sorcerer and witch interchangeably in this paper to refer to both genders.

3 Many of these accounts deal with the physical traces left by witches of their activities: magic bundles (of dirt, hair, animal parts and the like) placed in cradles or under thresholds by malevolent visitors, or the bits of wool sheared from sheep in odd places discovered after a witch's night visit to the sheep pen.

4. Orivesi, 1953: Hugo Hörtsänä, 936.

5 Orivesi, 1953/1933: Hugo Hörtsänä, 925.

6 All translations from the original Finnish are mine.

7 The term Karelia refers to a region historically populated by a Balto-Finnic people related culturally and linguistically to the Finns. Karelia lies on both sides of the present-day border between Finland and Russia.

8 See Gwyn Prins, 'Oral History', in Peter Burke (ed.), Nerw Perspectives on Historical Writing (Cambridge, 1991), pp. 119-20.

9 Michel de Certeau, The Practice of Everyday Life, trans. Steven Rendall (Berkeley, 1984).

10 Pierre Bourdieu, Outline of a Theory of Practice (Cambridge, 1977); Bourdieu, The Logic of Practice (Cambridge, 1990).

11 Keith Thomas, Religion and the Decline of Magic (London, 1971). 
12 Max G. Marwick, 'Witchcraft as a Social Strain-Gauge', Australian Journal of Science 26 (1964) 263-8.

13 See Thomas, Religion and the Decline of Magic.

14. George M. Foster, 'Peasant Society and the Image of Limited Good', American Anthropologist 67 (1965) 293-315.

15 Toivo Vuorela, Paha silmä suomalaisen perinteen valossa (Helsinki, 1960).

16 Similar to leeching, 'cupping' was a practice of drawing blood for therapeutic purposes that involved suctioning blood from small cuts using hollow horns.

17 Laura Stark-Arola, Magic, Body and Social Order: The Construction of Gender Through Women's Private Rituals in Traditional Finland (Helsinki, 1998), pp. 108-11.

18 Ilomantsi, 1938: A. Turunen S. 1: 342: Heikki Hassinen, 51 years.

19 Asikkala, 1967: J. Maunula, Kansantieto-lehti Kysely (Answers to the Questionnaire from the journal 'Folk Knowledge'), 1936-present. Helsinki: Finnish Literature Society (hereafter KT), 394: 137.

20 Stark-Arola, Magic, Body and Social Order, pp. 105-6.

21 T. M. Luhrmann, 'The Magic of Secrecy', Ethos 17 (1989) 131-65.

22 Stark-Arola, Magic, Body and Social Order, pp. 39-43.

23 Leppävirta, 1935-36: Hannes Koskinen, Kalevalan riemuvuoden kilpakeräys (Collection Contest in Honour of the 10oth Anniversary of the Kalevala), 1935-6. Helsinki: Finnish Literature Society (hereafter KRK), 104: 17: Pekka Itkonen, 69 years; Nousiainen, 1930: F. Leivo, 25; Nilsiä, 1961: Aatto V. Korhonen, Tarinakilpailu (Tale Competition), 1961. Helsinki: Finnish Literature Society (hereafter TK) 37: 51: Collector's father Adolf Korhonen (died 1935).

24. See Anna-Leena Siikala, Suomalainen šamanismi (Helsinki, 1992), pp. 108-11.

25 Satu Apo, 'Alkoholi ja kulttuuriset tunteet', in Sari Näre (ed.) Tunteiden Sosiologiaa II (Helsinki, 1999), pp. 101-44.

26 Sääminki, 1939: J. Vaahtoluoto, 419.

27 Valtimo Pyhäjärvi, 1955: Siiri Oulasmaa, 3116: Lempi Suurkoski.

28 Uukuniemi, 1935-36: Eino Kuutti, KRK, 143: 88: Toivo Mustajärvi, 50 years.

29 In the late nineteenth-century rural countryside, parishioners had to bring to the parsonage each year a certain amount of their produce, usually in the form of butter or cheese. In some cases parsons went from farm to farm every year to collect their butter, hence the comparison here between the itinerant sorcerer and a clergyman.

30 Kitee, 1921: Pekka Vauhkonen, Vähäisiä keräelmiä (Minor Collections), 1900-1930s. Helsinki: Finnish Literature Society (hereafter $V K$ ), 107: 1.

31 Pälkjärvi, 1961: Olga Hirvonen, TK, 17: 155: Antti Eschner, b. 1875.

32 Koivisto, 1935-36: Väinö Santamo, KRK, 138: 23: Regina Rautanen, 76 years.

33 Anger can be thought of as the key component in Finnish-Karelian magical harm carried out by not only tietäjäs but ordinary persons as well. This was associated with the archaic belief that all persons possessed a supernatural force known as luonto, which 'rose' sometimes uncontrollably when one was angry. Because the tietäjä's luonto-force was seen to be harder (and sharper) than that of others, his luonto could penetrate the luonto of other persons, causing them physical or mental illness. See Stark-Arola, 'The Dynamistic Body in Traditional Finnish-Karelian Thought: väki, vihat, nenä, and luonto', in Anna-Leena Siikala (ed.), Myth and Mentality: Studies in Folklore and Popular Thought, Studia Fennica Folkloristica 8 (Helsinki, 2002).

34. Valtimo, 1939: Jorma Partanen, 1124: Pekka Tuovinen, 45 years.

35 Liperi, 1935-36: Tommi Korhola, KRK, 157: 143: Aapeli Ihalainen, 43 years.

36 Stark-Arola, Magic, Body and Social Order, pp. 78-81.

37 See Juha Pentikäinen, Oral Repertoire and World View: An Anthropological Study of 
Marina Takalo's Life History, Folklore Fellows' Communications 219 (Helsinki, 1978), pp. 68-9, 220.

38 The 'dog' referred to any agent of harm sent by magical means, including an illness, curse, snake or bear sent to attack an enemy's cattle. In all of these cases, the dog was sent home by the tietäjä who spoke the words: 'Mene koira kottii.

39 Only tietäjäs who still had their teeth or carried iron objects in their mouths were considered to be supernaturally or magically powerful. See Stark-Arola, 'The Dynamistic Body in Traditional Finnish-Karelian Thought'.

40 The non-gendered Finnish pronoun hän here does not indicate whether the supposed perpetrator of the sorcery was male or female.

41 Kitee, 1921: Pekka Vauhkonen, VK: 107, 1.

42 On the other hand there are mentions that when a sorcerer was brought to court on charges unrelated to magic, such as refusal to repay a debt, he might perform (secret) magic aimed at bewitching the judge and jury and taking revenge on his accusers.

43 Also: Orivesi, 1941: Hugo Hörtsänä, 3548: Otto Sinkala, elderly farm master; Orivesi, 1932: Hugo Hörtsänä: Kustaava Välilä, eyewitness, born 1854 .

44. Climbing backwards up a tree in the forest near the fields belonging to one's enemy was believed to be a common means of summoning a bear to attack that enemy's livestock, mentioned in numerous narratives.

45 Jyväskylä Korpilahti, 1945: J. Hyvärinen, 2665: Nikla Majander, born 1875.

46 Matti Peltonen, Talolliset ja torpparit: vuosisadan vaihteen maatalouskysymys Suomessa (Landowners and Crofters: The Peasant Question in Finland at the Turn of the Century) (Helsinki, 1992).

47 Pylkönmäki, 1935-36: Otto Harju, KRK, 70: 614: Otto Puttonen, 85 years.

48 Berries could be picked freely in the forest by everyone, and might be exchanged by poorer households for staple foodstuffs.

49 Tervo, 1935-36: Anna Heimonen, KRK, 92: 1069: Edla Heimonen, b. 1864. Parentheses are original.

50 Two narratives from South Karelia describe a magical punishment for the rape of a young woman. In them, a curse is uttered against the culprit which transforms his sexual organs ('May your organ always swell/ May it always stand like a pole/ And never be satisfied/ May it even be erect on your deathbed') so that he is doomed to 'chase wildly after women all his life, even though all the women were afraid of him and called him "Ville the Bull". Here we can speculate that in a community which believed in the effectiveness of the curse, it may have been enough for the rumours and narratives of both the rapist's act and the frightening new condition of his genitalia (which few would bother to confirm for themselves) to circulate throughout the community in order for him to be shunned (Koivisto, 1935-36: Ulla Mannonen, KRK, 129: 792: Ulla Kallonen, 79 years).

51 For example, Juva, 1914: Lauri Taskinen, $V K$, 98: b) 8: serving maid Hilma Väisänen, approximately 30 years of age.

52 Keuru, 1935-36: Alma Viitanen, KRK, 51: 108: Heikki Kurra, deceased, crofter.

53 Stark-Arola, Magic, Body and Social Order, pp. 169-72.

54. Stark-Arola, Magic, Body and Social Order, pp. $211-23$.

55 Stark-Arola, Magic, Body and Social Order, pp. 222-3.

56 Stark-Arola, Magic, Body and Social Order, pp. 218-23.

57 Utajärvi, 1966: V. Lohi, 2484: Maija Ryynänen.

58 See Willem de Blécourt, 'On the Continuation of Witchcraft', in Jonathan Barry, Marianne Hester and Gareth Roberts (eds), Witchcraft in Early Modern Europe: Studies in Culture and Belief (Cambridge, 1996), pp. 335-52. 